\title{
RASY WYŻSZE, RASY NIŻSZE. O POPULARYZACJI WIEDZY NA TEMAT RÓŻNORODNOŚCI LUDZKIEJ NA ZIEMIACH POLSKICH W DOBIE POZYTYWIZMU
}

\author{
SUPERIOR RACES, INFERIOR RACES: \\ ON POPULARIZATION OF KNOWLEDGE \\ ON HUMAN DIVERSITY IN THE POLISH LANDS \\ IN THE ERA OF POSITIVISM
}

\begin{abstract}
This article aims at demonstrating why an attitude to view the human diversity according to a criterion of race originated in the society in the epoch of Positivism. It is an outline of a specific approach of Polish popular science to popularize achievements of word science in the field of anthropology. The fact that races exist was then taken for granted and efforts were made to describe them. Readers of periodicals were acquired with racial classifications based on geographical and morphological criteria, often evaluating civilizations of individual races and the races themselves.

Opinions of both foreign and Polish scientists, travelers and journalists were influenced by Eurocentric world view, and consequently the recognition of a white man, his appearance, activities and civilization, as a pattern that should be followed and imitated by all others in the name of human progress. The term 'race' itself was not defined; moreover, it was used without consistency and arbitrarily, and frequently interchangeably with such terms as 'generation,' 'people,' 'branch,' 'tribe' and 'nation.' Despite the aboundance of press publications on human races, the knowledge of this notion did not became a systematic one. Notions specific for the then anthropology became more widely known, and the glorification of colonial
\end{abstract}

KATARZYNA WRZESIŃSKA Instytut Slawistyki Polskiej Akademii Nauk, Warszawa

E-mail: katarzyna.wrzesinska@ispan.waw.pl http://orcid.org/0000-0002-5533-5540

CITATION: Wrzesińska, K. (2019) Rasy wyższe, rasy niższe. O popularyzacji wiedzy na temat różnorodności ludzkiej na ziemiach polskich w dobie pozytywizmu. Sprawy Narodowościowe. Seria nowa, 2019(51). https://doi.org/10.11649/sn.1813

This work was supported by the National Science Center (number 2016/21/B/HS3/03696) No competing interests have been declared.

This is an Open Access article distributed under the terms of the Creative Commons Attribution 3.0 PL License (creativecommons.org/licenses/by/3.0/pl/), which permits redistribution, commercial and non-commercial, provided that the article is properly cited. (C) The Author(s) 2019

Publisher: Institute of Slavic Studies, Polish Academy of Sciences 
successes of the white man helped enforce a conviction of his superiority over "wild races" and support cruelty in the name of progress. However, Polish positivist thought approached scientific racism with criticism. [Trans. by Jacek Serwańsk]]

Key words: Positivism; human races; hierarchy of races; reception of racial theories; Eurocentrism; science popularization

Streszczenie

Celem artykułu jest ukazanie jednej z dróg, która przyczyniła się do zakorzenienia w polskim spoteczeństwie myślenia o różnorodności ludzkiej podług wartościującego kryterium rasy. W tekście została zarysowana specyfika popularnonaukowego ujęcia tego problemu w dobie pozytywizmu. Dążono wówczas do upowszechnienia zdobyczy nauki światowej w dziedzinie antropologii. Przyjmowano jako pewnik istnienie ras, starano się je opisać. Na łamach czasopism zaznajamiano czytelnika z klasyfikacjami rasowymi opartymi na kryteriach geograficznych i morfologicznych, z czasem wartościującymi, wyżej lub niżej oceniającymi zdobycze cywilizacyjne poszczególnych ras i same rasy. Na rozważaniach zarówno zagranicznych jak i polskich badaczy, podróżników i popularyzatorów wiedzy piętno wywarł światopogląd europocentryczny, a w związku z tym uznanie człowieka białego - jego wyglądu, jego działań i jego cywilizacji - za wzorzec, któremu inni powinni się podporządkować w imię ogólnoludzkiego postępu. Nie definiowano samego terminu "rasa", ponadto używano go bez większej konsekwencji, dowolnie, a często zamiennie z takimi pojęciami jak "pokolenie", "lud", „szczep", „plemię", a także "naród". Wielość materiału prasowego na temat ras ludzkich nie usystematyzowała więc wiedzy na ich temat. Spopularyzowano słownictwo charakterystyczne dla ówczesnej antropologii, a gloryfikując kolonizacyjne dokonania „białego człowieka”, umocniono przekonanie o jego wyższości nad „rasami dzikimi”, oswojono z okrucieństwem dokonywanym w imię postępu. Polska refleksja pozytywistyczna była jednak krytyczna wobec rasizmu naukowego.

Stowa kluc zow e: pozytywizm; rasy ludzkie; hierarchizacja ras; recepcja teorii rasowych; europocentryzm; popularyzacja wiedzy

Ciemnota daleko prędzej niż wiedza, obudza pewność.

(F. S., 1871, s. 7)

$\mathrm{N}$ a ziemiach polskich po powstaniu styczniowym istniało równolegle wiele priorytetowych kwestii wymagających działania człowieka. Zadaniem pozytywistów stało się unowocześnienie społeczeństwa polskiego, wprowadzenie go na drogę nieustannego postępu, tak by ostatecznie było ono w stanie dorównać innym społecznościom europejskim, a w rezultacie stać się pełnoprawnym członkiem świata Zachodu. W pewnym więc sensie klęska zbrojnego zrywu stanowi nowe otwarcie na przyszłość. Jednym z pól ożywionej działalności młodego pokolenia stała się popularyzacja wiedzy. W coraz większym stopniu umożliwiała ją modernizacja rynku wydawniczego, przede wszystkim pod zaborem rosyjskim, oraz postępująca równolegle walka z analfabetyzmem. Następowała specjalizacja czasopism. Ich redaktorzy i autorzy tekstów w nich publikowanych stanowili polską elitę intelektualną. Posiadali różne wykształcenie: legitymowali się dyplomami uniwersyteckimi, ale równie często byli samoukami - wszyscy zaś niewątpliwie byli pasjonatami wiedzy i postępu. Poprzez różnorodne periodyki, by 
wymienić dla przykładu takie tytuły jak „Wędrowiec”, „Wszechświat”, „Biblioteka Warszawska”, "Ateneum”, "Kłosy” czy "Przegląd Tygodniowy” i „Prawda”, dążyli do upowszechnienia informacji na temat zdobyczy naukowych na świecie, kształtowania się nowych dziedzin nauki, innowacji technicznych, odkrywczych podróży, teorii i hipotez, które towarzyszyły poszerzaniu się wiedzy o człowieku i świecie. Prezentowano również osiągnięcia polskiej nauki, z pełną świadomością, że nie ma ona odpowiednich warunków do rozwoju.

Spośród wielu kierunków, jakimi podążali polscy myśliciele i popularyzatorzy wiedzy, warto wybrać i przybliżyć ten, jak się wydaje podstawowy i zasadniczy, a mianowicie prowadzący ku zgłębieniu tajemnicy życia człowieka na Ziemi: początków tegoż życia, przyczyn zróżnicowania rodzaju ludzkiego, zasadności podziału gatunku (lub gatunków) ludzkiego na rasy, wpływowi samej rasy na zdolności fizyczne, umysłowe i moralne człowieka, czy wreszcie konieczności cywilizowania ludów dzikich. Znaczenie poruszanego tematu jest tym większe, że wartościowanie ras oraz sam język ich opisu, niejednokrotnie z dzisiejszego punktu widzenia ośmieszający i pogardliwy, nie pozostały bez wpływu na kształtowanie się postaw społecznych wobec różnorodności i odmienności ludzkiej.

\section{SPECYFIKA POLSKIEJ POZYTYWISTYCZNEJ MYŚLI O CZŁOWIEKU I RASACH LUDZKICH}

Cechą charakterystyczną pozytywistycznego ujęcia analizowanego problemu było dążenie do kreowania obrazu człowieka na podstawach poświadczonych przez naukę. Odejście od ideału gabinetowego uczonego nie dokonało się jeszcze wówczas w pełni, ale poczęto przykładać wage do wiarygodności informacji i wielości wykorzystywanych przy pracy źródeł. Niestety chęć zdobycia czytelnika niejednokrotnie przekładała się na publikowanie sensacyjnych doniesień, zwłaszcza na temat ludów dzikich, zamieszkujących odległe od Europy krainy. W przesądy i zabobony wierzyli nie tylko ludzie słabo wykształceni. Jak pisał Filip Sulimierski (Domarańczyk, 2015, ss. 25-32), geograf, niestrudzony popularyzator wiedzy, redaktor "Wędrowca", rozpowszechniali je też uczeni. „Teorii nie sprawdzają, często mówią być może, iż, lub nie wiadomo czy". Dotyczyło to również nauk przyrodniczych, w tym antropologii. Dalej wywodzit:

Skoro nasze wiadomości i obserwacje nie wystarczają dla objaśnienia danego faktu, poczekajmy chwilkę cierpliwie, a doczekamy się niezadługo, iż ktoś inny, na drodze spokojnego i umiejętnego badania, wyprowadzi ten nowy fenomen, jako konieczne następstwo, z dawnych praw natury. Precz za to raz na zawsze z tym pozornym tłumaczeniem czegoś niejasnego przez coś jeszcze mniej jasne (...); precz z tym odwoływaniem się do rzeczy, która nie istnieje jeszcze, do jakiegoś nieznanego, nieodkrytego prawa natury (F. S., 1869a, ss. 47-48).

Powołując się na Johna S. Milla, Sulimierski dzielit wszystkie mylne przekonania na: błędy aprioryczne, wynikające z subiektywnych odczuć, płynące z uogólniania, z pomieszania pojęć i wreszcie błędy pochodzące z fałszywego rozumowania. Te ostatnie uznawał za najliczniejsze, jak na przykład stwierdzenie, że „murzyni nigdy nie będą tak oświeceni jak biali". Krytykował ponadto mechanizm rozciągania obserwacji miejscowych na większy obszar, sądzenie z teraźniejszości o przyszłości, z jednego narodu o drugim (F. S., 1869b, s. 72). Przestrogi te nie ustrzegły publicystów i uczonych przed pochopnymi i fałszywymi sądami. Równocześnie ceniono dzieła naukowe, powstające w wyniku wielolet- 
nich systematycznych badań. Dlatego też na bieżąco starano się na łamach gazet informować o nowościach zagranicznych, a wydawcy jak i redakcje czasopism podejmowały trud przekładu na język polski prac uznawanych za znaczące i wartościowe. Nie było to praktyką nową, ale ten kierunek ruchu wydawniczego przybrał znacznie na sile. Tu starczy wymienić m.in. polskie wydania Charlesa Darwina (F. S., 1871, ss. 6-8)'1, Oskara Peschela („Oskar Peschel”, 1876, s. 186), Edwarda B. Tylora, czy Herberta Spencera (jako dodatek dla stałych prenumeratorów warszawskiego "Głosu”). Powstające w drugiej połowie XIX wieku czasopisma popularnonaukowe podjęły misję zaznajamiania czytelnika polskiego z dorobkiem nauki światowej i literaturą podróżniczą. Treść numerów stanowiły początkowo w większości omówienia publikacji zagranicznych. W przypadku "Wędrowca" najczęściej korzystano z treści zawartych we francuskim piśmie podróżniczym „Le Tour du Monde". Z czasem zaczęły się pojawiać oryginalne teksty polskie (m.in. relacje z podróży). "Wszechświat" z kolei publikował artykuły na podstawie angielskich czasopism "Nature" i "Science”, francuskich „Revue d'Anthropolgie” i "Revue d'Scientifique” oraz niemieckiego "Archiv für Anthropologie" i innych. "Prawda”, nie będąc stricte czasopismem popularnonaukowym, prawie w każdym numerze zamieszczała teksty upowszechniające nowe ustalenia z różnych dziedzin wiedzy, a poziom ich był znacznie wyższy niż tych publikowanych w "Wędrowcu".

Specyfikę piśmiennictwa pozytywistycznego stanowiła więc recepcja nauki obcej. Opowiadano się za ewolucjonizmem nie tylko Darwinowskim, dotyczącym świata roślin i zwierząt, ale także ewolucjonizmem w ogóle, w każdej dziedzinie, np. w geologii (teoria Charlesa Lyella obalająca Cuvierowską koncepcję katastrof) (Kontkiewicz, 1890, ss. 97-102). Przyjęcie "transformistycznej” koncepcji Darwina doprowadziło do stanowczej krytyki kreacjonistycznej teorii powstania świata („Krótki pogląd”, 1874, ss. 91-94; F. Sulimierski, 1867, ss. 235-237). Rola Opatrzności i biblijne wyjaśnienia dotyczące pochodzenia człowieka i jego różnorodności zostały zanegowane. Były one jednak obecne W piśmiennictwie polskim jeszcze w drugiej połowie XIX wieku (Duchiński, 1901, s. 141; Szujski, 1867, s. 23), a w publikacjach o charakterze katolickim funkcjonowały znacznie dłużej. Rozbieżność opinii w powyższych kwestiach tak skomentowano na szpaltach "Wędrowca":

Z powodu zaciętej u nas szermierki piśmienniczej i ustnej o pozytywizm, słusznie ktoś przyrównał oba przeciwne obozy do byków hiszpańskich, wpadających we wściekłość na widok czerwonej szmaty. Dla jednych taką szmatę stanowią nazwiska Darwina, Huxleya, Littre'go, Haeckel'a, dla drugich wzmianka o jezuitach, inkwizycji, metafizyce i wodzie z Lourdes ( „Nowości", 1875, s. 139; podobnie "Granice", 1873, s. 63; F. Sulimierski, 1879, s. 49).

$\mathrm{Na}$ łamach gazet odzwierciedlenie znalazł także spór między monogenistami a poligenistami, czyli zwolennikami pochodzenia człowieka z jednego źródła, a stojącymi na stanowisku, iż gatunek ludzki powstał niezależnie w wielu miejscach na ziemi. Pomimo różnorodnych dyskusji, nowych publikacji i teorii, nie było rzadkie stwierdzenie, że w zasadzie jest rzeczą niezbadaną, w jaki sposób powstał „ród ludzki”. Wedle Karla Vogta, jak relacjonował publicysta „Wędrowca”, nic nie potwierdzało owej pierwotnej jego jedności, natomiast, jak daleko wszędzie w przeszłość sięgnąć, wszędzie dostrzec można "różne rasy ludzi". A więc, jak wywodził niemiecki uczony, zarówno różnorodność ras jak i ich

1 W 1873 r. ukazała się po polsku jedynie część dzieła Darwina w tłumaczeniu W. Mayzla, pełne tłumaczenie S. Dicksteina i J. Nusbauma pod tytułem O powstawaniu gatunków drogą naturalnego doboru czyli o utrzymywaniu się doskonalszych ras w walce o byt ukazało się na przełomie lat 1884/85 w Warszawie nakładem „Przeglądu Tygodniowego". 
trwałość - "niezmienność typów" - w ciągu wieków należało uznać za pewnik (W. K., 1886a, s. 201). W nauce polskiej zarówno Ludwik Krzywicki (Hołda-Róziewicz, 1969, ss. 649-659), jak i Ludwik Gumplowicz (W. K., 1886a, ss. 201-202) byli poligenistami. Pierwszy z uczonych z czasem jednak opowiedział się za Darwinowskim ujęciem, uznającym jedną tylko parę pierwotną, i wyjaśniającym późniejsze zróżnicowanie ludności odmiennością klimatu w różnych rejonach ziemi, innymi warunkami stwarzanymi przez otaczającą przyrodę, różnorodnością pokarmu ( „Kilka słów”, 1874, s. 100).

Często dyskutowany problem stanowiło zjawisko dziedziczności (Gawin, 2003, ss. 43-52; Kaufman, 1886, ss. 544-545; Nusbaum, 1887, ss. 625-628). Zdawano sobie sprawę, z powtarzalności pewnych cech w ramach gatunku ludzkiego, nie umiano jednak sformułować jednej zasady, która wyjaśniałaby całokształt problemu. Darwin za Lamarckiem powtórzył tezę o dziedziczności cech nabytych. Mimo różnych doświadczeń, których rezultaty ją obalały (ucinanie przez Augusta Weismanna kolejnym pokoleniom myszy ogonów, a rodzenie się następnych w dalszym ciągu z ogonami) (Rozicki, 1891, s. 581), przez dziesięciolecia w nauce nie było zgodności w tej kwestii. Poprzez pryzmat dziedziczności rozważano problem krzyżowania się ras ludzkich - również nie było zgody co do tego, czy proces taki wydaje pozytywne czy negatywne skutki, ponieważ znajdowano przykłady i jednych, i drugich (Lud. Krzyw., 1888b, ss. 473-475).

Prezentując różnorakie poglądy na temat ras ludzkich, ostatecznie stwierdzano, przywołując autorytety takich badaczy jak Rudolf Virchow, Julius Kollman, Thomas Huxley i Ludwig Rutimeyer, że „(...) zupełnie odrębnych, czystych w znaczeniu antropologicznym ras, dziś nigdzie nie ma" (W. K., 1886b, s. 212). Niezmiennym jednak pozostawał fakt, że równocześnie $w$ istnienie owych ras wierzono i sukcesywnie starano się je wszystkie odkrywać, obserwować i opisywać.

W kontekście stwierdzanej przez naukę światową różnorodności ras ludzkich zastanawiano się nad stopniem ich przydatności w doskonaleniu cywilizacji. Za tę jedyną najbardziej wartościową uważano zachodnią, europejską i na jej podobieństwo ksztattującą się w Stanach Zjednoczonych Ameryki. Ewolucjoniści (np. Edward B. Tylor, Lewis H. Morgan, z polskich uczonych Krzywicki) nie przypisywali przyrodzonej i niezmiennej niższości ludom dzikim - traktowali je jedynie jako pozostające na wczesnym etapie rozwoju, takim, poprzez który musiały przejść i narody Europy w zamierzchłej przeszłości (Lud. Krzyw., 1888a, s. 461; "Z dziejów cywilizacji”, 1886, ss. 268-269). Nie ustrzegło to jednak ani uczonych, ani publicystów, a z pewnością polityków przed hierarchizowaniem ludów (ras) podług, jak to określano, stopnia ich cywilizacji. Te słabsze, kulturowo odmienne, oceniane jako prymitywne, bałwochwalcze, bezrozumne a z wyglądu ohydne i odrażające zostały skazane na wymarcie. W wielu polskich publikacjach podkreślano walory kolonizacji lądów zamieszkiwanych przez dzikie ludy. Choć jednocześnie ubolewano nad losem wyniszczanej przez Europejczyków ludności, to jednak w ogólnym rozrachunku przeważała duma z „człowieka białego", który (na terenie Ameryki Północnej) „(...) pozakładał kwitnące miasta, pobudował drogi, kanały i fabryki, usilną pracą użyźnił grunt, (...) zużytkował lasy i stepy, wydobył z tona ziemi skarby liczone na miliony” („Far-West”, 1869b, ss. 194-195).

Nauka światowa stanowiła inspirację dla polskich badaczy. W 1856 roku powstała Katedra Antropologii na Uniwersytecie Jagiellońskim (po paryskiej jako druga w Europie), od 1874 roku działała Komisja Antropologiczna przy Akademii Umiejętności, prace badawcze prowadził ośrodek Iwowski, żywa była jeszcze pamięć o wileńskim (Bielicki, Krupiński, Strzałko, 1987, ss. 3-6; Hołda-Róziewicz, 1969, s. 649). W Warszawie nie przepuszczano żadnej okazji, by nie dociekać źródeł odmienności między ludźmi. Objeżdżające stoli- 
ce Europy cyrki, które prezentowały grupy Indian, Eskimosów, czy Murzynów (Boëtsch, Blanchard, 2014, ss. 185-195), nie tylko ściągały podekscytowaną widownię, ale również miejscowych badaczy - antropologów i etnologów. Ci zaś, nie mając takich możliwości jak uczeni angielscy, francuscy czy niemieccy, korzystali z takich sposobności, by mierzyć czaszki, badać proporcje ciała, zachowania i wygląd egzotycznych przybyszów. Tak uczynił dr Leon Dudrewicz, pediatra a zarazem antropolog, w 1884 roku, kiedy Indianie z plemienia Omaha, objeżdżając Europę, zatrzymali się w Warszawie (Dudrewicz, 1884, s. 353; Hordyński, 1884, ss. 286-287). W Paryżu od 1878 roku działało Towarzystwo Antropologiczne i Etnograficzne Polskie (Malinowski, 1986, ss. 7-9; „Wystawa antropologiczna", 1878, s. 270). Coraz większą wagę zyskiwała socjologia, choć przez cały omawiany okres brakło jej na ziemiach polskich oparcia instytucjonalnego. Autorzy polscy starali się publikować w periodykach zagranicznych. Rodzity się kolejne inicjatywy wydawnicze poświęcone upowszechnianiu wyników badań etnograficznych nad ludnością zamieszkującą ziemie polskie ("Lud") oraz krajoznawstwu („Wisła”), także archeologiczne („Światowit”) i historyczne ( „Przegląd Historyczny", „Kwartalnik Historyczny”). Z końcem XIX wieku ten nurt dociekań nad własną przeszłością, poszukiwań źródeł tożsamości, pierwocin więzi społecznych i narodowych na ziemiach polskich miał związek z ogólnoeuropejskim dążeniem do uzasadnienia praw bytowych państwa i narodu (w przypadku polskim tylko narodu) autorytetem nauki. Ona też, z czasem instrumentalnie wykorzystywana, stała się jednym z zaczynów rodzących się nacjonalizmów.

\section{NIUANSE I NIEJEDNOZNACZNOŚĆ TERMINOLOGICZNA}

„Prawda, że nauka o rasach zaledwie dopiero weszła w stadium badań ścisłych i poważnych (...)" (A. Sulimierski, 1872, s. 360), stwierdzał Artur Sulimierski. Antropologia fizyczna była najstarszą gałęzią tej wiedzy. Badano więc zróżnicowanie ludzkości pod względem biologicznym, zewnętrznym, ale często też konkretnym typom rasowym przypisywano właściwą im kulturę (Mincer, 2012, s. 118). Wielonurtowość i wielopłaszczyznowość tych zainteresowań badawczych, a także niejednokrotnie i powierzchowność, powodowała niekonsekwencję, z jaką podchodzono do pojęć określających różnorodność pośród ludzkości. Część nieścisłości mogła wynikać z dowolności przekładu na język polski, część z braku precyzji. Ponadto $w$ nauce i publicystyce polskiej doby pozytywizmu funkcjonowały, rzecz jasna, terminy stosowane wcześniej. Wszystko to sprawia, że można jedynie stwierdzić, że ród ludzki (pojęcie stosowane w dobie romantyzmu) dzielono w różnoraki sposób, ale bez wyraźnej konsekwencji. Znane były podziały według kryteriów geograficzno-morfologicznych, m.in. Karola Linneusza (1735), Johanna F. Blumenbacha (1775) oraz George'a Cuviera (1798) (Strzałko, 2009, ss. 274-275; Tyrała, 2005, ss. 13-35). Przytaczano też inne klasyfikacje ras i rozważania nad przyczynami odmienności wśród ludzi: Josepha Virey'a i Victora A. Malte Bruna („Plemiona ludzkie”, 1863a, s. 357); Monteskiusza, Jean Jacques Rousseau, a z nowszych Henry'ego T. Buckle'a (J. Obieżyświat, 1879, s. 363) i Jean Luis A. Quatrefagesa (Radliński, 1890a, ss. 651-653, 1890b, ss. 665-668). W "Wędrowcu”, w artykule poświęconym zadaniom antropologii, znajdujemy podział na rasy według zabarwienia skóry: rasa biała to inaczej kaukaska, żółta to mongolska, czarna - etiopska, a czerwona to amerykańska. Anonimowy autor jednak zastrzegat, że to bardzo ogólnikowy podział, oczywiste są trudności w klasyfikacji, jeśli się zważy, że każda z wysp 
Oceanii jest zamieszkiwana przez ludność odrębną od innych ("Słów kilka”, 1874, s. 101). Podziałów na rasy przybywało przez cały wiek XIX (Platz, 1892, s. 190). Uwzględniano różnorakie wyznaczniki o charakterze fizycznym, nie tylko kolor skóry i jego odcienie, ale także rodzaj włosów, których badano także przekroje. Tak uczynił Joseph Deniker (1901). Wyróżniono również rasy podług kształtu czaszek (Anders Retzius), co dało początek antropometrii oraz podług rozmieszczenia zębów ("Słów kilka”, 1874, s. 101). Większość tych klasyfikacji omówił krytycznie w „Prawdzie” Ludwik Gumplowicz (1884, ss. 110-111).

Ówczesna systematyka opierała się na obserwacjach wyglądu zewnętrznego, a więc na fenotypie. Równolegle jednak poczęto skłaniać się ku podziałom łączącym cechy fizyczne rasy z mentalnością i kulturą (Bogacki, 1881, s. 125), stąd rasy czynne i bierne (jak sądził uczony niemiecki Gustav Klemm), niewolnicze i wolne (czyli niewolników i panów) („O geograficznych błędach", 1881, s. 53), wyższe i niższe - według m.in. Georges'a Lapouge'a, Paula Topinarda i Karla Penki (Lud. Krzyw., 1888a, s. 462; W., 1892, ss. 51-52), wyróżniano je również, stosując jako kryterium tryb życia, a więc były to rasy koczownicze i osiadłe; dzielono je także podług stosunku do kobiet: na mniej i bardziej cywilizowane („Kronika geograficzna”, 1884, s. 59; "O położeniu kobiet”, 1885, ss. 350-351) - oczywiście z europocentrycznego punktu widzenia. Odosobnionym ujęciem był podział według rodzaju wznoszonych budowli: okrągłych „u pokolenia jeszcze dzikiego" i czworokątnych u "wszystkich ras cywilizowanych” („Mozambik”, 1877, s. 242). Rasy podzielono także stosując kryterium języka. Stąd wzięło się zróżnicowanie ludności zamieszkującej Europę na rasy słowiańską, germańską i romańską, choć początkowo, traktowano ją w całości jako jednorodną, zarówno w sensie fizycznym jak i kulturowym, cywilizacyjnym rasę indoeuropejską, aryjską (w literaturze niemieckiej indogermańską) („Południowa Europa”, 1878, s. 122; Potocki, 1892, ss. 628-629; "Przez Dolomity”, 1880, ss. 69-70)².

Różnorodność klasyfikacji wypływała z faktu, że badający rasy, głównie uczeni posiadający wykształcenie medyczne i przyrodnicze, bardzo szybko doszli do wniosku, że nie da się rozdzielić rodu ludzkiego jedynie na kilka wyraźnych kategorii fizycznych. Różnice między ludźmi okazywały się płynne pod każdym względem. Doprowadziło to zresztą do bardzo cennego wniosku, a mianowicie, że żadna rasa nie jest tworem stały i niezmiennym. Nie wszyscy Indianie byli jednakowo czerwoni, a Murzyni jednakowo czarni, Europejczycy tak samo biali, a Azjaci żółci („O rasach”, 1871, ss. 158-160). Rysy twarzy również wykazywały odchylenia od konkretnego typu, przypisywanego danej rasie. Wreszcie badacze uznali, a jako jeden z pierwszych Charles Darwin, że pomijając różnice wynikające ze stopnia ewolucji i warunków życia, wszyscy ludzie są do siebie podobni pod względem przejawianych uczuć, ich duchowość ma zbliżone potrzeby, a rozwój kultury i techniki wszędzie i w każdych warunkach przebiega tak samo. O narzędziach np. pisano, że „(...) trudno odróżnić kamienny topór odkopany nad brzegami Sekwany od takiegoż samego topora, przywiezionego z Nowej Zelandii” („Okres kamienny”, 1866, s. 28). Jakiekolwiek jednak byłyby naukowe ustalenia, nie usunęły one chaosu terminologicznego, za który odpowiedzialni byli nie tylko badacze, ale także podróżnicy, publicyści, politycy i wszyscy inni, którzy czuli się uprawnieni do zabierania głosu w dyskusji o rasach.

Dopiero w dobie kształtujących się w Europie nacjonalizmów, poszukując dodatkowych bodźców dla umocnienia poczucia narodowego, zwrócono się ku poczuciu plemiennemu, wspólnocie krwi i rasy. Wtedy też renesans przeżyła, początkowo niezauważana, teoria rasowa Arthura de Gobineau. Pierwsza odnaleziona w prasie polskiej wzmianka o jego, określonej jako publicystyczna raczej niż naukowa, pracy Essai sur I'inegalite des races humaines pochodzi z 1886 r. (Krzywicki, 1886, s. 39), a następna z 1888 r. (Krzywicki, 1888, s. 186). Obydwie opierają się na drugim wydaniu pracy z 1884 r. 
Analizując piśmiennictwo popularnonaukowe, spotykamy szereg terminów na określenie różniących się między sobą populacji, i to używanych zamiennie. Z romantycznego ujęcia podziałów ludzkości, tak jak je przedstawiała historia naturalna, w drugiej połowie XIX wieku spotkać jeszcze można termin „pokolenie”, coraz częściej zastępowany pojęciem „rasa”. Inne określenia okazały się bardziej trwałe, były to takie pojęcia jak „szczep", „gałąź", „plemię", „lud”, „gromada” i „naród”; jeszcze inne pojawiały się efemerycznie i nie zawsze było wiadomo, co konkretnie oznaczają, jak np. „szczepy plemienne” („Obwód jakucki”, 1884, s. 35). Natomiast spotykane wcześniej sporadycznie określenie "rasa”, "gatunek" i „typ” zaczęły pojawiać się z większą częstotliwością, co miało niewątpliwie związek z rozwojem nauk biologicznych (Klecki, 1926), a następnie antropologicznych i powstawaniem kolejnych typologii rasowych. Jak już wspomniałam, autorzy różnorodnych refleksji dotyczących bezpośrednio nauk o człowieku: medycyny, etnologii, etnografii, antropologii, socjologii, ale także opisów podróżniczych, relacji z wypraw związanych z poznawaniem mało zbadanych pozaeuropejskich lądów, czy z ich kolonizacją, nie dbali o precyzję terminologiczną. Nie było zjawiskiem odosobnionym, że w ramach jednego tekstu padały niemal wszystkie możliwe pojęcia na określenie jednej i tej samej populacji. I tak dla przykładu, anonimowy autor publikacji w "Wędrowcu", opisując w 1863 roku podział ludzkości, używa następujących terminów: „plemiona”, "rassy”, gruppy”. Ustala ponadto swego rodzaju hierarchię: "szczep” to określenie całości rodu ludzkiego (to wyjątkowy przypadek), natomiast na tworzące go "plemiona" lub „rassy” składają się "ludy", w innym zaś fragmencie tekstu tworzą je "narody", jako jednostki najmniejsze („Plemiona ludzkie”, 1863, ss. 357-358). Idąc dalej tropem niekonsekwencji terminologicznych, ponownie widzimy podobną synonimiczność terminów przy opisie ludności Maroka. Oprócz Maurów „(...) istnieją [tam - K.W.] jeszcze cztery inne rassy: arabowie, berbery, murzyni i żydzi. (...). Pięć tych plemion stoi wrogo przeciw sobie, nienawidzi się (...)" („Marokko”, 1865, s. 123). Także w opisie ludności Brazylii czytamy, że każdy jej mieszkaniec przynależy "do innego szczepu lub plemienia"; ",ludy i plemiona (...) spotykają się tutaj i łączą w najściślejsze stosunki (...)”, dochodzi do „ciągłego mieszania się rass" („Notatki”, 1867, s. 276). Cyganów w jednej z publikacji określa się jednocześnie jako „rase”, "zagadkowe plemię" i „pokolenie” („Legrenne”, 1868, s. 251). O łużyckich Słowianach czytamy, że to "maleńkie plemię", "ludek łużycki”, "małe wendzkie plemię", a wreszcie "łużycki naród” („O piśmiennictwie”, 1868, ss. 328 i 330). Polacy natomiast w jednym z tekstów to jednocześnie „plemię", „naród” i „rasa” - pojęcia użyte synonimicznie przy omawianiu kondycji fizycznej Polaków (Popławski, 1886, s. 181).

Inny rodzaj dowolności rodził niewątpliwie poziom przekładu na język polski. Sprawdzenie, z jaką konsekwencją i dbałością o oddanie właściwego terminu dokonywano tłumaczeń z języków obcych, przekracza ramy niniejszego artykułu. Można jednak przypuszczać, że często przekład stanowił licentia poetica tłumacza. W "Wędrowcu” spotykamy się z krytyką przekładów, noszących piętno dowolności, zmienianych na polecenie wydawcy lub według własnego uznania („Nowości. Krajowe”, 1876, s. 286).

W przytłaczającej większości tekstów poświęconych różnorodności ludzkiej, opisywanej przy rozmaitych okazjach, nie zadawano sobie trudu, by zdefiniować używane terminy. Stosowano je przemiennie, często jedynie kontekst wypowiedzi (i wiedza czytelnika) umożliwiał uporządkowanie chaosu. Polegać to mogło na ustanowieniu pewnej gradacji rodziny tych pojęć. U szczytu stałby wówczas gatunek ludzki jako całość (lub gatunki, Julien J. Virey opowiadał się za dwoma gatunkami ludzi, bardziej i mniej uzdolnionym) (Virey, 1857, ss. 200-245), dalej rasy (czyli, by użyć przestarzałego określenia - pokolenia), 
następnie zaś plemiona i współtworzące je szczepy. Taki układ widoczny był w większości przytaczanych w czasopismach klasyfikacji rasowych. Naród właściwie w ramach żadnej się nie mieścit, był bowiem każdorazowo mieszaniną różnorodnych rasowo (etnicznie) składników. Należy jednak zwrócić uwage, ze spotkać można zamienne stosowanie terminów "rasa” i "naród”, stąd np. „rasa polska” („Wędrówki”, 1885, s. 233).

\section{HIERARCHIZACJA, CZYLI WARTOŚCIOWANIE RAS}

Antropologia fizyczna dzieliła rasy podług fizycznych wyznaczników, o czym była już mowa. Klasyfikacje nie wartościowały, lecz wyróżniały rasy według określonych cech wyglądu zewnętrznego. Jednakże biali podróżnicy, za nimi często gabinetowi uczeni, opierający się na mało wiarygodnych lub tylko pojedynczych, relacjach, w dalszej kolejności publicyści, z czasem politycy poczęli hierarchizować rasy podług innych kryteriów: możliwości rozwoju umysłowego, moralności itp. A ponieważ zdobywcami w ówczesnym świecie byli ludzie biali, to właściwy im wzorzec cywilizacyjny i wynikający stąd poziom i tryb życia, a także wygląd zewnętrzny stały się punktem odniesienia, swoistym kryterium oceny wszystkich ludzi od tego kanonu odmiennych. Trzeba jednak dodać, że tego rodzaju poglądy nie dominowały.

Jednolitości rasy białej, indoeuropejskiej upatrywano w pierwotnej wspólnocie językowej (sanskryt) (Baudouin de Courtenay, 1881, ss. 198-199; "Franciszek Bopp", 1867, ss. 350-351; „Pokrewieństwo języków”, 1885, s. 521; „Rasy ludzkie”, 1871, s. 190)³. Utożsamiono ją błędnie z jednością w sensie biologicznym, fizycznym (k-i., 1891, ss. 221-222). Uważano, że „ludy składające to plemię" (tu z kolei termin „plemię" zostaje użyty zamiennie z pojęciem „rasa”) „(...) stoją w porównaniu z innymi na najwyższym stopniu rozwoju umysłowego, one reprezentują ludzkość i postęp (...), przodując w sztukach, naukach i historycznej działalności” („Plemiona ludzkie”, 1863a, s. 357). Dalej w tym samym tekście czytamy, że umysłowe zdolności ludzkie tym wyżej są rozwinięte, im ludzie maja jaśniejszą cerę ("Plemiona ludzkie”, 1863b, s. 382). W innym miejscu (tekst tłumaczony z francuskiego) przyznawano jednak, że wszystkie rasy mają zdolność do przyjęcia cywilizacji. Są one jednak „surowe i często instynktowne u murzyna", a u Mongoła "silne a ciasno ograniczone". Dopiero w przypadku rasy białej (kaukaskiej), dzielącej się na "dwa wielkie rody mianowicie: indogermański i semitycki” („O rasach”, 1871, s. 159), zdolności te

(...) stają się (...) potęgą prawie bez granic. Właściwa historia tyczy się wyłącznie plemienia białego. Cywilizacja jest jego prawdziwym dziełem, a wszystkie społeczeństwa utworzone z innych plemion są tylko naśladowaniem niedokładnym, niezręcznym lub wstrętnym (...). (...) potęga jego twórczości zdaje się niewyczerpana, a płodność kombinacji nieograniczona. Jego tylko praca doznaje błogosławieństwa, bo ona jedna przynosi rzeczywiste owoce („O rasach", 1871, s. 160).

Podejmowano próby, jak to określano, cywilizowania ludów dzikich. W niejednakowy sposób przyjmowały one te działania kolonizatorów. Pomijając całą złożoność problemu, tu jedynie wskażę na kwestię rasy. Otóż uważano, powołując się na uznany autorytet w dziedzinie antropologii - Petera Broca, że w rozmaitych rasach ludzi, podobnie jak u zwierząt, istnieją wielkie różnice zdolności i usposobień. Indywidualne cechy albo

3 W tekście poświęconym Boppowi pada termin „naród” jako określający wspólnotę ludów indoeuropejskich. 
ułatwiają cywilizowanie, albo utrudniają, mogą je też uczynić niemożliwym - „Jedne rassy są zdolne do doskonalenia się (perfectibles), drugie zdają się nie mieć wcale tej zdolności (...)" ("Swojskie”, 1866, s. 247)4. Tak więc nie była rzadką opinia, że „(...) tylko pod pilnym i ostrym dozorem nabiera murzyn fizycznej i moralnej wartości, tylko jako podrzędny staje się pożyteczna istotą" („Krajowcy”, 1885, s. 334). Nie było odosobnionym zjawiskiem to, że uczeni - m.in. Josiah C. Nott, George R. Gliddon, Louis Agassiz - swoimi teoriami rasowymi wspierali politykę państw europejskich, które kolonizując nowe terytoria, czyniły sobie tubylców całkowicie podległymi bądź przyczyniały się do ich wymierania, usprawiedliwiając podboje wyższością rasową białych (Krzywicki, 1888, s. 186).

Natomiast Carl Ritter, niemiecki geograf, uważał, że „wszystkie pokolenia ludzkie” biorą udział w dziele doskonalenia się - „nawet murzyni mają siłę do wyjścia z pieluch przyrodzenia”. Jednakże „cywilizacja prawdziwa”, to ta, w której człowiek najmniej jest zależny od natury dzięki „szczególnej energii moralnej”, która umożliwia mu pokonywanie przeszkód; „przymiot ten stanowi całą wyższość rasy kaukaskiej nad innymi (...)" („Rozwój", 1868, s. 238).

Rasizm naukowy usprawiedliwiał podboje terytorialne, tworzył mniemanie nie tylko o słuszności podejmowanych działań, ale wręcz ich konieczności. Tak oceniano sytuację na Dalekim Wschodzie, gdzie typowa „odrętwiałość" Azjatów (z Indii, Birmy, Syjamu i Chin) musiała w końcu ustąpić przed "moralną i fizyczną" oraz "duchową wyższością" Europejczyków („Na wschodzie”, 1869, s. 31). Opinie takie jak powyższa, także w odniesieniu do rozmaitych innych ludów, były poprzez ówczesną umysłowość przeciętnego Europejczyka przyswajane jako naturalne i oczywiste. Polski fotograf i podróżnik Henryk Filipowicz podobnie negatywnie osądzał mongolskie ludy Syberii, kolonizowane przez "rasę wyższą" - „rasę wielkoruską" (Filipowicz, 1869, s. 284). Ujęcie rosyjskie nie było, rzecz jasna, odmienne. B. Wereszczagin, relacjonując swą podróż w głąb Rosji, oceniat, że Rosjanie uzyskują przewage nad „krajowcami” dzięki sile swej armii oraz wyższości cywilizacji europejskiej nad „pół-dzikimi rasami Azji Środkowej”, „rasami muzułmańskimi i barbarzyńskimi" (Wereszczagin, 1873, s. 6). W przypadku Samojedów anonimowy autor stwierdzał, że „(...) podległość rasie wyższej przerabia stopniowo dzikiego (...) na ucywilizowanego człowieka” („Nad Morzem”, 1882, s. 358). Również panowanie Anglików w Indiach oceniano z uznaniem, biorąc pod uwagę cywilizacyjny postęp, który przynosiła ze sobą kolonizacja. Akceptowano rozdział pomiędzy Anglikami a ludnością miejscową. Tłumaczono, że "oliwkowata cera, zdradzająca podejrzenie pewnego procentu krwi indyjskiej w żyłach, jest dostatecznym powodem, żeby kogoś trzymać z daleka". Tacy ludzie „(...) nie mogą się równać z towarzystwem europejskim, tak pod względem fizycznym i moralnym, jak i intelektualnym" (Garbe, 1889, s. 501).

Często powtarzającym się motywem w prasie popularnonaukowej była kwestia przypisywanego ludom podbijanym, jako należącym do ras niższych, wrodzonego marazmu. Streszczając wywody L. Simonina, A. Sulimierski pisał z ogromnym żalem, że Indianie, "rasa czerwona” tak hojnie obdarzona w urodzajne ziemie „(...) nie ruszyła ani krokiem na drodze postępu". Za to "rasa amerykańska" - powstała nie tylko z "rasy anglo-saksońskiej", ale wszystkich innych przybyszów na ląd Ameryki Północnej: Niemców, Francuzów, Włochów, Belgów i Skandynawów - jest niesłychanie pracowita, pełna inicjatywy, przejawia "męskość charakteru”, stoicyzm wobec trudności, a kobietę otacza głębokim szacunkiem („Far-West”, 1869a, s. 217). Z większości tego typu tekstów nie przebija

\footnotetext{
4 Przywołano pracę P. Broca, Discussion sur la perfectibilite des races, „Bulletins de la Société d'antropologie de Paris", 1860
} 
jakiekolwiek współczucie wobec podbijanych ludów, proces ich wymierania traktuje się jako naturalną, wobec rozwoju cywilizacji, kolej rzeczy.

W latach 60. XIX wieku u szczytu europejskiej elity stały, jak pisano, „ludy anglosaxońskiego szczepu", „(...) owa rasa niezaprzeczenie najwyżej ucywilizowana, a przy tym śmiała i przedsiębiorcza, nieraz aż do awanturniczości” („Nowa”, 1865, s. 407). Nieustanne dążenie do postępu, jak fatum zawisło nad ludami, które żyły inaczej. Kolonizacja w każdym zakątku ziemi przebiegała pod hasłem walki z barbarzyństwem i dzikością i jak deklarowano, walka ta miała być spełnieniem obowiązku wobec ludzkości, który polegał na cywilizowaniu. Istniała świadomość gwałtów dokonywanych na tubylcach w różnych zakątkach ziemi, ale były one usprawiedliwiane celem uważanym za wyższy (Pomian, 2005, ss. 397-398).

\section{EUROPOCENTRYCZNY SPOSÓB POSTRZEGANIA RASOWEGO PIĘKNA}

Nie popełni się chyba błędu, uznając, że rasa jawi się najczęściej jako pewna wyraźna kategoria związana z czystością typu. W dobie rozkwitu nauk przyrodniczych nie stanowiły rzadkości porównania między rasami ludzkimi a rasami zwierząt. W przypadku tych ostatnich, przede wszystkim hodowanych przez człowieka, konieczny był każdorazowo jakiś określony wzorzec, pożądany w zależności od potrzeb ludzkich. Główne rasy ludzkie, na podobieństwo zwierzęcych też stanowiły odpowiednio takie wzorce, dla każdej rasy zaś ideał piękna był odmienny (Krzywicki, 1886, s. 39). Dlatego też dla człowieka białego najpiękniejszym był drugi biały (ewentualnie innego koloru ale wykazujący uderzające podobieństwo w rysach twarzy i ogólnym wyglądzie do białego).

Już w latach 60. XIX wieku zwrócono uwage na kształt czaszki i zauważono, co następuje:

Niskie, jakby w tył uciekające czoło, z wystającymi naprzód szczękami, oznacza w człowieku zwierzęcość, i czyni go najbardziej zbliżonym do czworonożnych. Postępując od plemion ludzkich, stojących na niższym stopniu zmysłowego wykształcenia coraz dalej, aż do ludzi, którzy stanowią chlubę rodu naszego, widzimy zmieniający się kształt czaszki, nie tyle pod względem objętości, ile co do harmonii części jej między sobą. Najdoskonalsza harmonia taka stanowi to, co nazywamy pięknością, w rozległym znaczeniu tego wyrazu („Plemiona ludzkie”, 1863b, s. 382).

Choć zdarzało się, że dostrzegano cielesne piękno wśród ludów dzikich, to jednak przeważały opisy o charakterze wartościującym, negatywnie odnoszące się zarówno do wyglądu jak i sposobu zachowania, trybu życia - niecywilizowanego. Uderza sam język opisu, dziś nie do przyjęcia, w XIX wieku stosowany powszechnie i uznawany za stosowny (Gawin, 2003, s. 23). Używano rozmaitych określeń, by ostatecznie udowodnić niższość poznawanej i podbijanej ludności. Czynili tak zarówno autorzy polscy, jak i obcy. I tak w relacji Ludwika Niemojowskiego, zesłanego na Syberię, Czukcze to „znikczemnione istoty” (Niemojowski, 1872a, s. 133), a Kamczadale to ludzie „(...) należący do nierozwiniętych i skarłowaciałych moralnie ras", choć ich język, w przeciwieństwie do dźwięków wydawanych przez Czukczów, „podobny jest do mowy ludzkiej” (Niemojowski, 1872b, s. 152), natomiast „rysy twarzy Mongołów i Sajańców są monstrualnie brzydkie (...), czynią z nich prawdziwe potwory. Kobiety mongolskie są jeszcze bardziej odrażającej powierzchowności od mężczyzn" (Niemojowski, 1872c, s. 369). 
Na temat rasy etiopskiej, często zwanej rasą negrów, pisano, nie szczędząc odstręczającej charakterystyki. I tak, „czarnych portugalskiej Gwinei” postrzegano jako "(...) odznaczających się nadzwyczajną brzydotą i silnym nieprzyjemnym odorem. Mimo że myją się (...), są zawsze równie brzydcy i wstrętnie pachnący (...)" („Krajowcy”, 1885, s. 334). Anonimowy autor podkreślał niezdolność opisywanej ludności do jakiegokolwiek rozwoju. Opisywał ją jako "(...) więcej do zwierzęcia podobną" ("Krajowcy”, 1885, s. 334). Sygurd Wiśniowski krytykował podejście pisarzy do tematu Indian Ameryki Północnej, ponieważ uważał, że idealizowali oni odwagę i „rycerskość dziczy smagłej”, tworząc łzawe romanse. A tymczasem:

Gdy się jednak raz widziało ohydę ich pożycia, kobiety wynędzniałe od brutalstwa, pracy nad sity (...), mężczyzn tucznych, spędzających życie całe w śnie, żarłoctwie lub na koniu, znika nie tylko poezja, lecz i żal się czuje ku pisarzom, co przedstawiając sobkostwo i lenistwo w różowych kolorach, zwichnęli nasze pojęcia o rzetelnej potrzebie wprowadzenia cywilizacji między ludy, niegodne jeszcze, by je za ludzi uważano (Wiśniowski, 1876, s. 242).

"Czerwonoskórcy" jednak, jak pisano, „(...) doznali zaszczytu poetycznej pieśni; dzicy i brudni murzyni australijscy nie zdołają natchnąć żadnego poety” („Dzicy”, 1877, s. 34).

Ci ostatni uważani byli za lud stojący pod każdym względem najniżej.

Specyfikę pozytywistycznego oglądu różnorodności ludzkiej stanowiło dążenie do naukowego badania rzeczywistości. Towarzyszyła temu pogłębiona recepcja nauki obcej. Zapoczątkowany w latach 60. XIX wieku na ziemiach polskich rozwój kultury masowej umożliwił zetknięcie się społeczeństwa z egzotyką, poznanie odmiennych kultur i ludów, choć było ono naznaczone europocentrycznym piętnem, poczuciem wyższości białego człowieka. Nastąpiło upowszechnienie wiedzy na temat pochodzenia człowieka oraz różnorodności rodzaju ludzkiego. Wielość przytaczanych jego klasyfikacji, wynikająca z odmienności stosowanych kryteriów podziału na rasy, zamiast porządkować, rodziła wiele znaków zapytania. Ostatecznie nie rozwiano wątpliwości dotyczących problemu dziedziczenia, wartości krzyżowania ras dla rozwoju gatunku ludzkiego, w dalszym ciągu dyskutowali między sobą zwolennicy jego monogenezy i poligenezy. Niewątpliwie upowszechnił się sam termin „rasa”, choć stosowany w sposób niejednoznaczny, najczęściej jednak wówczas, gdy opisywano typ ludności, która wyróżniała się jakimiś charakterystycznymi cechami fizycznymi, moralnymi, kulturowymi. Jeśli mielibyśmy szukać źródeł rasizmu, należałoby się skupić właśnie na drugiej połowie XIX wieku, gdy piśmiennictwo, będące odzwierciedleniem epoki, zaczęło oswajać z okrucieństwem wobec ludzi innych i słabszych, traktując je jako normę. Warto zwrócić uwagę, że niekoniecznie trzeba było używać terminu „rasa”, by wartościować ludzi. Starczał tu specyficzny język opisu, który z jednych czynił panów, z drugich zaś niewolników.

W niniejszym artykule dzięki analizie tekstów popularnonaukowych wykazano, że postrzeganie ludzkości poprzez pryzmat rasy stało się powszechną i akceptowaną praktyką. W cechach fizycznych człowieka upatrywano czynnika decydującego o jego rozwoju cywilizacyjnym. Z końcem drugiej połowy XIX wieku także pośród narodów europejskich doszukiwano się rasowych przesłanek, które miały decydować o wyższości jednych, a niższości drugich. Nauka i popularyzacja wiedzy zostały wprzęgnięte do polityki. Badania nad problematyką ras ludzkich w XIX wieku ukazują źródła ksenofobicznych i rasistowskich postaw, także dzisiejszych uprzedzeń wobec Innego czy Obcego. Pozwalają rozstrzygnąć wątpliwości terminologiczne dotyczące samego pojęcia „rasa” i jego stosowania, co ma znaczenie dla analiz nie tylko historycznych. 
Baudouin de Courtenay, J. (1881). Pogadanki naukowe: O gramatyce porównawczej języków indoeuropejskich. Prawda, 1881(17), 198-199.

Bielicki T., Krupiński T., Strzałko J. (1987). Historia antropologii w Polsce. Przegląd Antropologiczny, 1987(1-2), 3-28.

Boëtsch G., Blanchard P. (2014). From Cabinets of Curiosity to the "Hottentot Venus": A Long History of Human Zoos. W N. Bancel, T. David, D. Thomas (Ed.), The Invention of Race. Scientific and Popular Representation (ss. 185-195). New York-Abington: Routlege.

Bogacki, F. (1881). Tajemnice życia duszy. Prawda, 1881(11), 125-126.

Domarańczyk, D. (2015). Regionalista z pasją dalekich podróży, czyli Filip Sulimierski i jego "Wędrowiec". Acta Universitatis Lodziensis: Folia Litteraria Polonica, 2015(3), 25-32.

Duchiński, F. H. (1901). Zasady dziejów Polski i innych krajów słowiańskich i Moskwy. W F. H. Duchiński, Pisma Franciszka Duchińskiego (T. 1). Rapperswyl: Muzeum Narodowe Polskie. [1. wyd.1858].

Dudrewicz, L. (1884). Kilka słów o czerwonoskórcach z pokolenia "Omaha” pod względem antropologicznym. Wszechświat, 1884(23), 353-356.

Dzicy w Australii. (Dokończenie). (1877). Wedrowiec, 1877(3), 34.

F. S. [Sulimierski, F.]. (1869a). Nasze przesądy. (Dalszy ciąg). Wędrowiec, 1869(341), 47-48.

F. S. [Sulimierski, F.]. (1869b). Nasze przesądy. (Dokończenie). Wędrowiec, 1869(343), 72.

F. S. [Sulimierski, F.]. (1871). Darwin o pochodzeniu człowieka. Wędrowiec, 1871(79), 6-8.

Far-West amerykański, podług L. Simonin'a opisał Artur Sulimierski. (1869a). Wedrowiec, 1869(350), 217.

Far-West amerykański, podług L. Simonin'a opisał Artur Sulimierski. (1869b). Wędrowiec, 1869(351), 194-195.

Filipowicz, H. (1869). Teleuci czyli Biali-Kałmycy, studium przez Henryka Filipowicza. Wedrowiec, 1869(331), 284.

Franciszek Bopp. (1867). Wędrowiec, 1867(230), 350-351.

Francuski protektorat w Tahiti. (Dokończenie). (1865). Wędrowiec, 1865(109), 67.

Garbe, R. (1889). Życie Europejczyków w Indiach, przez Ryszarda Garbe. Wedrowiec, 1889(42), 500-501.

Gawin, M. (2003). Rasa i nowoczesność: Historia polskiego ruchu eugenicznego (18801952). Warszawa: Wydawnictwo Neriton.

Granice chłopskiego rozumu. (1873). Wedrowiec, 1873(186), 63.

Gumplowicz, L. (1884). Najnowszy stan kwestii rasowej. Prawda, 1884(10), 110-111.

Hołda-Róziewicz, H. (1969). Prace antropologiczne Ludwika Krzywickiego na tle początków antropologii polskiej. Kwartalnik Historii Nauki i Techniki, 1969(4), 649-659.

Hordyński, B. (1884). Historia pokolenia Omaha. Wędrowiec, 1884(24), 286-287.

J. Obieżyświat. (1879). Z kroniki spółczesnej Brazylii. Wędrowiec, 1879(127), 362-364.

k-i. [Krzywicki, L.]. (1891). Kwestia aryjska. Prawda, 1891(19), 221-222.

Kaufman, M. (1886). Dziedziczność i teoria doboru w świetle nowych badań biologicznych. Prawda, 1886(46), 544-545.

Kilka słów o zadaniach antropologii. (1874). Wędrowiec, 1874(216), 100.

Klecki, W. (1926). Zasady nauki hodowli gospodarskich zwierząt domowych. Poznań: WIR.

Kontkiewicz, S. (1890). Najnowsze teorie geologiczne powstawania gór, lądów i zagłębi morskich. Wszechświat, 1890(7), 97-102. 
Krajowcy archipelagu Bissago. (1885). Wędrowiec, 1885(29), 334-335.

Kronika geograficzna. Geologia. Geografia i Podróże. Nowe Hebrydy. (1884). Wędrowiec, 1884(6), 59.

Krótki pogląd na naukę o pochodzeniu istot żyjących. (1874). Wędrowiec, 1874(214), 91-94.

Krzywicki, L. (1886). Jak powstaje pojęcie o pięknie cielesnym (szkic z porównawczej antropologii). Gtos, 1886(3), 39-41.

Krzywicki, L. (1888). Rasa a społeczeństwo. Głos, 1888(16), 185-185.

Legrenne. (1868). Wędrowiec, 1868(302), 251.

Lud. Krzyw. [Krzywicki, L.]. (1888a). Zagadnienia antropologiczne. Prawda, 1888(39), 461-462.

Lud. Krzyw. [Krzywicki, L.]. (1888b). Zagadnienia antropologiczne. Prawda, 1888(40), 473-475.

Malinowski, A. (1986). Sześćdziesięciolecie działalności Polskiego Towarzystwa Antropologicznego. Przegląd Antropologiczny, 52(1-2), 7-14.

Marokko i marokkanie. (1865). Wędrowiec, 1865(138), 123.

Mincer, T. (2012). Kulturowe rozumienie pojęcia rasy. Prace Kulturoznawcze, 2012(1), 117-128.

Mozambik (Dalszy ciąg). (1877). Wędrowiec, 1877(16), 242.

Na wschodzie. (1869). Wedrowiec, 1869(315), 31-32.

Nad Morzem Białym. (1882). Wedrowiec, 1882(49), 357-359.

Niemojowski, L. (1872a). Pierwotne plemiona Syberii: Studium etnograficzne, przez Ludwika Niemojowskiego. Wedrowiec, 1872(139), 133.

Niemojowski, L. (1872b). Pierwotne plemiona Syberii: Studium etnograficzne, przez Ludwika Niemojowskiego. Wedrowiec, 1872(140), 152.

Niemojowski, L. (1872c). Przejażdżka po stepach. (Dokończenie). Wędrowiec, 1872(152), 369.

Notatki z podróży po Brazylii. (Dokończenie). (1867). Wędrowiec, 1867(252), 276.

Nowa Kolumbia. (1865). Wędrowiec, 1865(130), 407.

Nowości. (1875). Wedrowiec, 1875(296), 139.

Nowości. Krajowe. (1876). Wedrowiec, 1876(357), 286.

Nusbaum, J. (1887). Nowsze poglądy na istotę dziedziczności. Wszechświat, 1887(40), 625-628.

O geograficznych błędach na których opierają się historiograficzne poglądy profesora Duchińskiego. (1881). Wędrowiec, 1881(239), 52-53.

O piśmiennictwie serbo-łużyckim. (1868). Wędrowiec, 1868(307), 328-330.

O położeniu kobiet u różnych ludów i plemion, z Leturneau. (1885). Wędrowiec, 1885(30), 350-351.

O rasach ludzkich, przez Emila Montegut. (1871). (Z. Grabowska, Tłum.). Wedrowiec, 1871(62), 158-160.

Obwód jakucki we Wschodniej Syberii. (1884). Wedrowiec, 1884(3), 35-36.

Okres kamienny w Europie. (1866). Wędrowiec, 1866(184), 28.

Oskar Peschel. (1876). Wedrowiec, 1876(351), 186.

Platz, B. (1892). Człowiek, jego pochodzenie, rasy i dawność (K. Jurkiewicz, Tłum.). Warszawa: Nakład Maurycego Orgelbranda. [1. wyd. 1887].

Plemiona ludzkie. (1863a). Wedrowiec, 1863(23), 357-358.

Plemiona ludzkie. (Dokończenie). (1863b). Wędrowiec, 1863(24), 382.

Pokrewieństwo języków europejskich. (1885). [wg pracy R. Zawilińskiego, O stosunku pokrewieństwa języków aryo-europejskich, Kraków 1885]. Wędrowiec, 1885(44), 521. 
Południowa Europa. Podług Elizeusza Reclus (przekład M. J. Bierz...). (1878). Wędrowiec, 1878(87), 120-122.

Pomian, K. (2005). Niższe? Wyższe? Równe? Cywilizacja europejska wobec innych. Przegląd Historyczny, 2005(3), 391-401.

Popławski, J. L. (1886). Ciekawe cyfry. Głos, 1886(12), 180-181.

Potocki, J. K. (1892). Ginące ludy. Wędrowiec, 1892(40), 628-629.

Przez Dolomity: Wycieczka koleją żelazną z Ponteba. (1880). Wędrowiec, 1880(187), 69-71.

Radliński, I. (1890a). Teoria Quatrefagesa o pochodzeniu ludności polinezyjskiej. Wszechświat, 1890(41), 651-653.

Radliński, I. (1890b). Teoria Quatrefagesa o pochodzeniu ludności polinezyjskiej, (Dokończenie). Wszechświat, 1890(42), 665-668.

Rasy ludzkie, III, przez Emila Montegut. (1871). (Z. Grabowska, Tłum.). Wędrowiec, 1871(64), 190.

Rozicki, H. T. (1891). Odziedziczanie kalectw nabytych. Prawda, 1891(49), 580-581.

Rozwój produkcyjności zaeuropejskich krajów. (1868). Wędrowiec, 1868(301), 238.

Słów kilka o zadaniach antropologii. (1874). Wędrowiec, 1874(216), 101.

Strzałko, J. (2009). Darwin jako antropolog ewolucyjny: Problem ras ludzkich. Kosmos: Problemy nauk biologicznych, 2009(3-4), 273-278.

Sulimierski, A. (1872). Z dziedziny geografii, podał Artur Sulimierski, (Dalszy ciąg). Wędrowiec, 1872(127), 360.

Sulimierski, F. (1867). Przegląd nowych odkryć i wynalazków. Wędrowiec, 1867(223), 235-237.

Sulimierski, F. (1879). Nowe teorie Haeckla. Wędrowiec, 1879(134), 49.

Swojskie zwierzęta. (1866). Wedrowiec, 1866(198), 247-250.

Szujski, J. (1867). Rys dziejów piśmiennictwa świata niechrześcijańskiego. Kraków: Drukarnia „Czasu” W. Kirchmayera.

Tyrala, R. (2005). O jeden takson za dużo: Rasa jako kategoria społecznie problematyczna. Warszawa: Oficyna Naukowa.

Virey, J. J. (1857). Historia naturalna rodu ludzkiego (P. E. Leśniewski, Tłum.) (T. 1). Warszawa: Nakładem i drukiem S. Orgelbranda.

W. (1892). Człowiek w przyrodzie (według Topinarda). Prawda, 1892(5), 51-52.

W. K. (1886a). Nowa teoria socjologiczna. Wedrowiec, 1886(17), 201-202.

W. K. (1886b). Nowa teoria socjologiczna. (Dalszy ciąg). Wędrowiec, 1886(18), 212-213.

Wereszczagin, B. (1873). Z Orenburga do Samarkandy, przez B. Wereszczagina. Wedrowiec, 1873(183), 6.

Wędrówki. (1885). Wędrowiec, 1885(20), 233.

Wiśniowski, S. (1876). Suowie i Amerykanie, przez Sygurda Wiśniowskiego. Wędrowiec, 1876(355), 242.

Wystawa antropologiczna w Paryżu, opisał dr Silex. (1878). Wędrowiec, 1878(95), 270.

Z dziejów cywilizacji: Według wykładu wstępnego p. Leturneau w szkole Antropologii w Paryżu. (1886). Wszechświat, 1886(17), 266-269. 